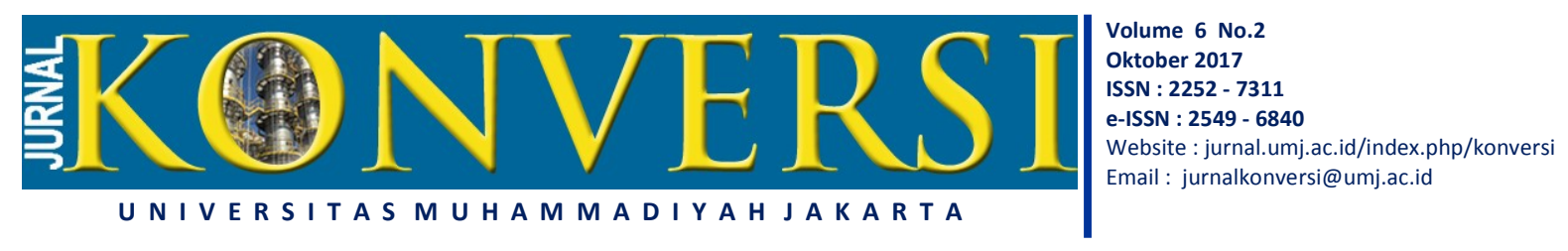

\title{
PENGARUH TEMPERATUR PENGERINGAN TERHADAP SWELLING DAN TENSILE STRENGTH EDIBLE FILM HASIL PEMANFAATAN PATI LIMBAH KULIT SINGKONG
}

\author{
Nufus Kanani ${ }^{1}$, Wardalia ${ }^{2}$, Endarto Y Wardhono ${ }^{3}$, Rusdi ${ }^{4}$ \\ Jurusan Teknik Kimia, Fakultas Teknik. Universitas Sultan Ageng Tirtayasa \\ nufuskanani@yahoo.com
}

\begin{abstract}
ABSTRAK
Pengemasan merupakan proses perlindungan suatu produk pangan yang bertujuan menjaga keawetan dan konsistensi mutu. Bahan pengemas dari plastik banyak digunakan dengan pertimbangan ekonomis, namun penggunaan material sintesis tersebut berdampak pada pencemaran lingkungan. Salah satu alternatif untuk menangani permasalahan tersebut dengan menggunakan material ramah lingkungan (biodegradable) seperti edible film. Penelitian ini bertujuan untuk mengkaji pengaruh temperatur pengeringan terhadap swelling dan tensile strength edible film hasil pemanfaatan pati limbah kulit singkong dengan penambahan ekstrak jahe merah. Penelitian ini diawali dengan tahap pembuatan ekstrak jahe merah dan pati dari limbah kulit singkong, setelah itu dilanjutkan dengan pembuatan edible film dengan variasi penambahan ekstrak jahe merah $(0.5-1.1 \% \mathrm{w} / \mathrm{v})$ dan diberi plasticizer berupa gliserol $(1 \% \mathrm{v} / \mathrm{v})$. Selanjutnya dilakukan tahapan pembuatan dan pencetakkan edible film dan pengeringan pada temperatur $\left(50 ; 60 ; 70^{\circ} \mathrm{C}\right)$. Hasil yang diperoleh selanjutnya dilakukan analisa swelling dan tensile strength. Hasil menunjukkan nilai swelling dan tensile strength tertinggi diperoleh pada pada penambahan ekstrak jahe merah $1.1 \%$ dan temperatur pengeringan $70^{\circ} \mathrm{C}$ yaitu masing-masing $88.89 \%$ dan 50,66 $\mathrm{kg} / \mathrm{cm}^{2}$.

Kata Kunci : Kemuluran, Kuat tarik, Lapisan edibel
\end{abstract}

\begin{abstract}
Packaging is a protection food product to maintain the quality and durability of food. Plastic packaging is widely used for economic consideration, but it leads to environmental pollution. The alternative way to handle this problem is by using biodegradable material such as edible film. This study aims to examine the effect of dying temperature on the swelling and tensile strength of edible cassava peel starch film with the addition of red ginger extract. This research was started with the extraction of red ginger and cassava peel starch, followed by edible film making with variation of red ginger extract addition $(0.5-1.1 \% \mathrm{w} / \mathrm{v})$ and glycerol $(1 \% \mathrm{v} / \mathrm{v})$ as plasticizer. The next stages were production and molding of the edible film. The edible films were then dried at the temperature of $\left(50 ; 60 ; 70^{\circ} \mathrm{C}\right)$. Furthermore swelling and tensile strength analysis was conducted to the product of edible film. The results showed that the highest swelling and tensile strength values were obtained on the addition of red ginger extract of $1.1 \%$ and the drying temperature of $70^{\circ} \mathrm{C}$ which were $88.89 \%$ and $50,664 \mathrm{~kg} / \mathrm{cm}^{2}$ respectively.

Keywords : Edible film, Swelling, Tensile strength
\end{abstract}




\section{PENDAHULUAN}

Menurut Suryana, 2005, ketahanan pangan merupakan ketersediaan bahan pangan dimana setiap individu mampu memperolehnya sebagai kebutuhan dasar serta ketahanan terhadap kondisi lingkungan untuk menjaga kualitas bahan pangan. Tanpa adanya perlindungan bahan pangan mengakibatkan kualitas semakin menurun salah satunya factor mikrobiologi adanya pencemaran terhadap jamur atau bakteri yang jumlahnya sangat banyak pada lingkungan terbuka. Salah satu upaya mengatasi ketahanan pangan adalah dengan memberikan pengemasan. Pengemasan merupakan proses perlindungan suatu produk pangan yang bertujuan menjaga keawetan dan konsistensi mutu. Bahan pengemas dari plastik banyak digunakan dengan pertimbangan ekonomis. Peningkatan laju konsumsi dan teknologi pangan meningkatkan pula laju pembuangan kemasan bekas bahan pangan di lingkungan hidup manusia. penggunaan materil sintesis tersebut berdampak pada pencemaran lingkungan. Sehingga mulai didapatilah masalah-masalah yang berasal dari sampah kemasan bahan pangan seperti plastik. Salah satu alternatif untuk menangani permasalahan tersebut dengan menggunakan material polimer ramah lingkungan (biodegradable).

Edible film didefinisikan sebagai lapisan yang dapat dimakan yang ditempatkan di atas atau di antara komponen makanan (Hui, 2006). Edible film mempunyai tiga komponen penyusun utama yaitu lemak, protein dan polisakarida. Lemak memiliki fungi sebagai barrier uap air terhadap suhu ruang, protein memiliki fungsi sebagai penghambat perpindahan gas, sehingga efektif untuk mencegah oksidasi lemak dan polisakarida berfungsi untuk mengatur udara sekitarnya dan memberikan ketebalan atau kekentalan pada larutan edible film. Polisakarida memiliki beberapa kekurangan yaitu sifatnya yang rapuh (mudah hancur) dan kurang elastis, sehingga dalam pembuatan edible film dengan kandungan polisakarida perlu adanya penambahan plasticizer guna meningkatkan sifat edible film, antara lain elongasi dan tensile 76 strength. Pemanjangan menunjukkan kemampuan rentang edible film yang dihasilkan.Penambahan sorbitol dapat meningkatkan nilai pemanjangan sehingga kerapuhan edible film menurun dan permeabilitasnya meningkat. Menurut Prihatingingsih, $2000 . \quad$ kekuatan peregangan (tensile strength) merupakan tarikan maksimum yang dapat dicapai sampai film tetap bertahan sebelum putus/sobek, yang menggambarkan kekuatan film [19]. Polisakarida seperti pati dapat digunakan sebagai bahan baku pembuatan edible film.

Pati merupakan homopolimer glukosa dengan ikatan $\alpha$-glikosidik. Pati terdiri dari dua fraksi yang dapat dipisahkan dengan air panas. Fraksi terlarut disebut amilosa dan fraksi tidak larut disebut amilopektin (Hui, 2006). Sumber pati salah satunya terdapat di tumbuhan singkong pada bagian daging dan kulit bagian dalam. Karena produksi singkong setiap tahun semakin meningkat maka limbah kulit singkongpun semakin banyak. Solusi mengatasi limbah tersebut dengan memanfaatkan kulit singkong sebagai bahan baku edible film karena mengandung $15-20 \%$ pati yang dapat dimanfaatkan (Farinet, 1991). Untuk mendapatkan edible film pati kulit singkong yang optimal dan tahan terhadap bakteri, pada penelitian ini menggunakan jahe merah. Tanaman jahe merah memiliki banyak manfaat terutama untuk kesehatan. Jahe merah mengandung zat antioksidan serta anti bakteri sehingga dapat menghambat pertumbuhan bakteri dan untuk memperoleh sifat edible film yang optimal dilakukan dengan penambahan plasticizer gliserol.

Edible film (edible coating) terbuat dari bahan yang dapat dimakan, serta dapat berfungsi sebagai penahan (barrier) perpindahan massa (seperti kelembaban, oksigen, lemak dan larutan), atau sebagai pembawa bahan makanan dan tambahan (aditif) juga untuk meningkatkan kemudahan penanganan makanan. edible film merupakan lapisan tipis yang dapat dimakan, yang digunakan pada makanan dengan cara pembungkusan, pencelupan dan penyikatan. Pembuatan edible film dengan pembungkusan dilakukan dengan pencetakan larutan edible film terlebih 
dahulu (metode casting) setelah terbentuk edible film sesuai dengan yang diinginkan barulah dapat diaplikasikan pada produk. Pencelupan atau coating dilakukan ketika edible film masih dalam bentuk larutan (cair) kemudian produk dicelupkan pada larutan edible film hingga produk terlapis secara merata. Penyikatan hampir sama dengan metode pencelupan. Perbedaan hanya terletak pada pengaplikasiannya saja. Penyikatan dilakukan saat edible film masih dalam bentuk larutan yang kemudian di aplikasikan pada produk menggunakan kuas agar merata. Pelapisan ini berfungsi untuk penahan (barrier) yang selektif untuk menghambat perpindahan gas, uap air dan bahan terlarut, sekaligus memberikan perlindungan mekanis (Gennadios, 1990).

Edible film mempunyai tiga komponen penyusun utama yaitu lemak, protein dan polisakarida. Edible film yang terbuat dari lipida pada umumnya baik digunakan untuk penghambat perpindahan uap air dibandingkan dengan edible film yang terbuat dari protein dan polisakarida. Lemak yang umum digunakan adalah asam lemak, yang merupakan barrier uap air terhadap suhu ruang. Jumlah karbondioksida dan oksigen yang kontak dengan produk merupakan salah satu yang harus diperhatikan untuk mempertahankan kualitas produk dan akan berakibat pula pada umur simpan produk (Hui, 2006). Film yang terbuat dari protein dan polisakarida pada umumnya sangat baik sebagai penghambat perpindahan gas, sehingga efektif untuk mencegah oksidasi lemak. Bahan protein yang digunakan untuk edible film adalah kasein, gelatin, protein kedelai dan protein jagung (zein). Polisakarida sebagai bahan dasar edible film dapat dimanfaatkan untuk mengatur udara sekitarnya dan memberikan ketebalan atau kekentalan pada larutan edible film (Krochta, 1994). Polisakarida memiliki beberapa kekurangan yaitu sifatnya yang rapuh (mudah hancur) dan kurang elastis, sehingga dalam pembuatan edible film dengan kandungan polisakarida perlu adanya penambahan plasticizer guna meningkatkan sifat edible film. Polisakarida yang digunakan yakni, turunan-turunan selulosa seperti metil selulosa (MC), hidroksi propilselulosa, hidroksi etilselulosa, karboksi metilselulosa (CMC), turunan pati seperti hidroksi enopil amilosa, alginat dan karagenan. Jadi secara tidak langsung ketiga komponen penyusun utama edible film berperan penting dan saling berhubungan untuk menjaga kualitas edible film tersebut.

Edible film dari polisakarida mempunyai keunggulan yang lebih baik dalam penghambatan gas terhadap uap air. Edible film juga mempunyai banyak keuntungan jika dibandingkan dengan pengemas sintetik yang tidak dapat dimakan, yaitu :

1. Edible film dapat dimakan bersamaan dengan produk yang dikemas, sehingga tidak ada pembuangan pengemas.

2. Film yang tidak dapat dikonsumsi dapat didaur ulang, sehingga tidak mengakibatkan pencemaran lingkungan. Hal ini dikarenakan film dibuat dari bahan-bahan yang dapat diolah kembali, sehingga lebih mudah diuraikan daripada bahan sintetik.

3. Edible film dapat diterapkan pada sistem pengemasan berlapis-lapis dengan edible film sebagai pengemas bagian dalam dan pengemas non edible film di bagian luar.

4. Film dapat berfungsi sebagai suplemen gizi pada makanan.

5. Film dapat berfungsi untuk memperbaiki sifat-sifat organoleptik makanan yang dikemas dengan memeberikan variasi komponen (pewarna, pemanis dan pemberi aroma) yang menyatu dengan makanan.

6. Film dapat digunakan sebagai pengemas satuan (individu) dari bahan makanan yang berukuran kecil. misalnya: kacang, biji-bijian dan strawberry (Gennadios, 1990).

Berikut adalah perbedaan karakteristik plastik sintesis dengan edible film berdasarkan fungsinya. 
Tabel 1. Perbedaan karakteristik plastik sintesis dengan edible film

\begin{tabular}{|c|c|}
\hline Plastik & Edible Film \\
\hline $\begin{array}{c}\text { Sulit terurai. Waktu penguraian } \\
\text { selama } 500-1000 \text { tahun }\end{array}$ & $\begin{array}{c}\text { Mudah terurai (Biodegradable). } \\
\text { Waktu penguraian } 1-2 \text { bulan }\end{array}$ \\
\hline Nilai pemanjangan $300-500 \%$ & Nilai pemanjangan 25-45\% \\
\hline Kuat Tarik $17-35 \mathrm{Mpa}$ & Kuat Tarik 2 Mpa \\
\hline $\begin{array}{c}\text { Menyebabkan kontaminasi pada } \\
\text { produk yang dibungkusnya }\end{array}$ & $\begin{array}{c}\text { Tidak menyebabkan kontaminasi } \\
\text { pada produk yang dibungkusnya }\end{array}$ \\
\hline Tidak dapat dimakan & Dapat dimakan \\
\hline Mengandung zat karsinogenik & Non-Karsinogenik \\
\hline
\end{tabular}

Sumber : bbp4b.litbang.kkp.go.id

\section{METODOLOGI PENELITIAN}

\section{Bahan dan Alat}

Penelitian ini menggunakan bahan berupa pati kulit singkong sebagai bahan baku. Jahe merah sebagai campuran pati singkong dan plasticizer berupa gliserol. Untuk peralatan yang dipakai pada penelitian ini antara lain sebagai berikut : Autoclaf, Cetakan, Erlenmeyer, Gelas Beker, Gelas Ukur, Hotplate, Kaca Arloji, Micro Pipet, Neraca analitik, Oven, Pipet Tetes, Spatula, Termometer dan Waterbath.

\section{Metode Penelitian}

Metode penelitian ini dilakukan dengan beberapa tahapan penelitian yaitu tahapan pembuatan ekstrak jahe merah, pembuatan pati kulit singkong, tahap pembuatan larutan pati kulit singkong terplastisasi gliserol, tahapan pembuatan edible film pati kulit singkong+ekstrak jahe merah.

a. Tahap ekstraksi jahe merah

Tahap ekstraksi jahe merah dilakukan dengan proses maserasi terlebih dahulu selama 3 hari dengan etanol sebagai pelaruti. Setelah itu hasil ekstraksi di lakukan waterbath pada suhu $40-45^{\circ} \mathrm{C}$. Kemudian hasil ekstrak jahe merah berupa serbuk kemudian ditampung dalam wadah.

b. Tahap pembuatan pati kulit singkong Tahap pembuatan pati kulit singkong dilakukan dengan memisahkan antara kulit dalam dan kulit terluarnya. Kemudian disortir dan dicuci dengan air hingga bersih, setelah itu kulit dalam yang didapat di giling hingga halus. Kemudian ditambahkan aquadest secukupnya dengan melakukan pengadukan dan dibiarkan 20 - 30 menit agar semua pati terlarut lalu melakukan penyaringan hingga pati terpisah dari ampasnya. Setelah itu filtrat dibiarkan hingga membentuk endapan. Setelah endapan terbentuk kemudian ditambahkan aquadest kembali agar semua impuritis yang masih tertinggal dalam endapan ikut terbawa dan dibiarkan hingga membentuk endapan kembali. Endapan yeng telah terbentuk kemudian dikeringkan hingga terbentuk pati.

c. Tahap pembuatan larutan pati kulit singkong terplastisasi gliserol

Larutan pati dengan konsentrasi 3\% dibuat dengan cara melarutkan pati dalam $1 \%(\mathrm{v} / \mathrm{v})$ aquades dan aduk secara konstan dengan menggunakan stirrer pada kondisi suhu ruangan selama 20 menit. $1 \%$ gliserol (v/v) ditambahkan kedalam larutan pati, aduk kontinyu selama 15 menit pada temperatur $70^{\circ} \mathrm{C}$.

d. Tahap pembuatan edible film pati kulit singkong + ekstrak jahe merah

Menambahkan ekstrak jahe merah pada larutan pati yang telah dibuat dengan konsentrasi $0.5,0.8,1.1 \%$ larutan pati+gliserol $(30 \mathrm{ml})$. Masingmasing homogenisasi dengan menggunakan stirrer selama 1 menit. Campuran film yang telah dibuat kemudian ditempatkan dalam cetakan. Pengeringan film dilakukan dengan temperatur $50^{\circ} \mathrm{C}$.

Metode penelitian yang dilakukan dapat dilihat pada gambar berikut 


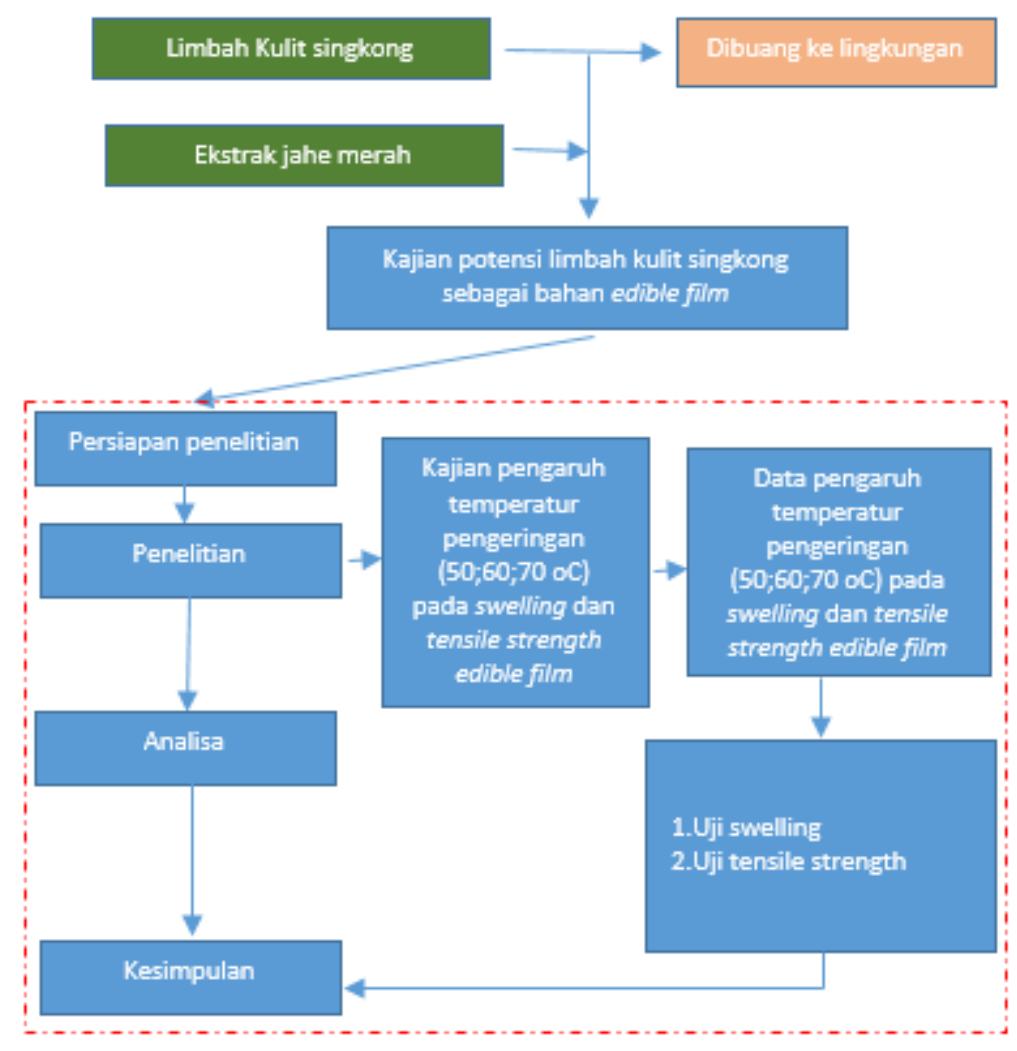

Gambar 1. Diagram alir percobaan

\section{HASIL PENELITIAN DAN PEMBAHASAN}

\section{Hasil Penelitian}

\section{a.Swelling}

Pengaruh penambahan ekstrak jahe merah pada nilai swelling yang diperoleh pada edible film dapat dilihat pada tabel berikut.

Tabel 2. Data Swelling dengan rasio pati singkong:aquades tetap

\begin{tabular}{|c|r|c|c|c|c|}
\hline $\begin{array}{c}\text { Ekstrak } \\
\text { jahe merah } \\
(\mathbf{\%})\end{array}$ & $\begin{array}{c}\text { Suhu } \\
\text { (oC) }\end{array}$ & $\begin{array}{c}\text { Ekstrak jahe } \\
\text { merah (\%) }\end{array}$ & $\begin{array}{c}\text { massa sebelum } \\
\text { (gr) }\end{array}$ & $\begin{array}{c}\text { massa sesudah } \\
\text { (gr) }\end{array}$ & $\begin{array}{c}\text { Swelling } \\
\text { (\%) }\end{array}$ \\
\hline \multirow{3}{*}{0,50} & 50 & 0,50 & 0,10 & 0,19 & 85,00 \\
\cline { 2 - 6 } & 60 & 0,50 & 0,08 & 0,12 & 43,75 \\
\cline { 2 - 6 } & 70 & 0,50 & 0,07 & 0,10 & 42,86 \\
\hline \multirow{3}{*}{0,80} & 50 & 0,80 & 0,15 & 0,24 & 60,00 \\
\cline { 2 - 6 } & 60 & 0,80 & 0,09 & 0,16 & 77,78 \\
\cline { 2 - 6 } & 70 & 0,80 & 0,07 & 0,13 & 85,71 \\
\hline \multirow{3}{*}{1,10} & 50 & 1,10 & 0,07 & 0,08 & 14,29 \\
\cline { 2 - 6 } & 60 & 1,10 & 0,10 & 0,19 & 90,00 \\
\hline
\end{tabular}




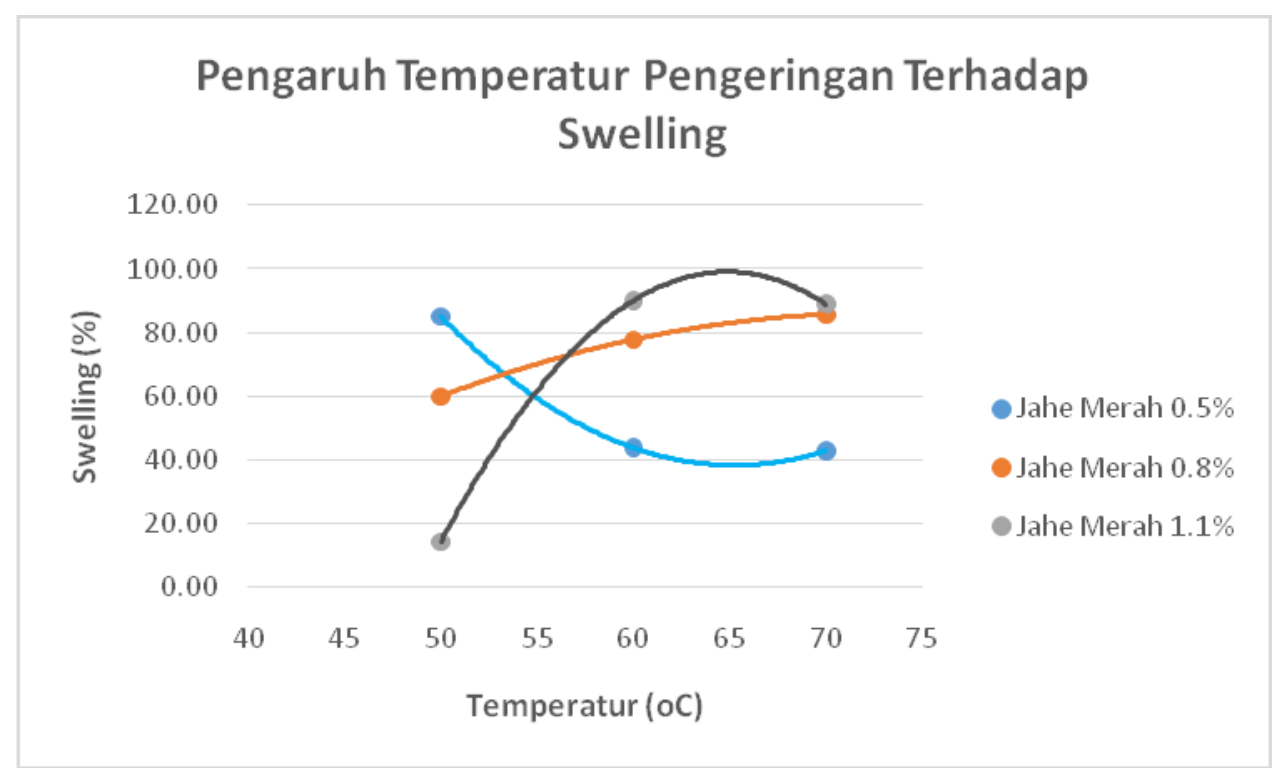

Gambar 2. Pengaruh Temperatur Pengeringan terhadap swelling

Dari gambar 2. dapat terlihat bahwa semakin banyak konsentrasi ekstrak jahe merah maka kadar air akan semakin rendah. Kechichian, 2010 mengungkapkan bahwa ekstrak jahe merah memiliki sifat hidrofobik sehingga sukar larut dalam air dan sulit terdispersi. Selain itu, dengan penambahan konsentrasi ekstrak jahe merah (serbuk gingerol) ke dalam larutan film akan mengakibatkan kemampuan film untuk menyerap air akan terhalang oleh partikel ektrak jahe merah (serbuk gingerol) mengakibatkan kemampuan penyerapan air semakin rendah. Dari grafik terlihat bahwa penyerapan kadar air (swelling) tidak hanya dipengaruhi oleh jumlah ekstrak jahe merah yang ditambahkan pada edible film solution, namun temperatur juga sangat mempengaruhi besarnya nilai swelling pada produk edible film yang terbentuk. Temperatur pengeringan sangat berpengaruh karena tingginya temperatur pengeringan yang digunakan akan mempengaruhi besarnya kandungan air yang dapat dihilangkan dari edible film yang terbentuk. Dari tabel terlihat bahwa semakin tinggi temperatur (pada temperatur $60{ }^{\circ} \mathrm{C}$ dan $70{ }^{\circ} \mathrm{C}$ ) yang digunakan maka berat kadar air yang terdapat pada edible film semakin rendah, namun setelah dilakukkan uji swelling, besarnya kadar air yang diperoleh (pada temperatur $60{ }^{\circ} \mathrm{C}$ dan $70{ }^{\circ} \mathrm{C}$ ) juga semakin tinggi karena semakin besar juga kemampuan edible untuk menyerap air, sebaliknya pada penggunaan temperatur $50{ }^{\circ} \mathrm{C}$ terlihat bahwa kadar air yang masih dimiliki masih lebih besar dibandingkan dengan penggunaan temperatur $60{ }^{\circ} \mathrm{C}$ dan $70{ }^{0} \mathrm{C}$, karena pada saat proses pengeringan masih banyak kadar air yang belum teruapkan sehingga pada saat dilakukan uji swelling kemampuan edible film untuk menyerap airpun masih rendah. Hal tersebut dapat terlihat dari data yang diperoleh setelah dilakukan percobaan, dimana nilai swelling tertinggi dan terendah diperoleh pada penambahan ekstrak jahe merah yang sama yaitu sebesar $1,1 \%$, namuan jika dilihat dari temperatur pengeringan yang digunakan pada proses pengeringan edible film dapat terlihat bahwa nilai swelling tertertinggi diperoleh pada penambahan ekstrak jahe merah sebesar $1,1 \%$ dengan temperatur pengeringan $70^{\circ} \mathrm{C}$ dan nilai swelling terendah diperoleh pada penambahan ekstrak jahe merah sebesar $1,1 \%$ dengan temperatur pengeringan $50^{\circ} \mathrm{C}$.

\section{b. Tensile Strength}

Hasil analisa tensile strength dapat dilihat pada tabel 2 dan gambar 3 . 
Tabel 3. Data Tensile strength

\begin{tabular}{|c|c|c|c|}
\hline $\begin{array}{c}\text { Ekstrak } \\
\text { jahe merah } \\
(\%)\end{array}$ & $\begin{array}{c}\text { Suhu } \\
(\mathrm{oC})\end{array}$ & $\begin{array}{c}\text { Ekstrak } \\
\text { jahe merah } \\
(\%)\end{array}$ & $\begin{array}{c}\text { Tensile } \\
\text { strength } \\
\left(\mathrm{kg} / \mathrm{cm}^{2}\right)\end{array}$ \\
\hline \multirow{3}{*}{0,50} & 50 & 0,50 & 35,66 \\
\hline & 60 & 0,50 & 47,82 \\
\hline & 70 & 0,50 & 23,93 \\
\hline \multirow{3}{*}{0,80} & 50 & 0,80 & 37,07 \\
\hline & 60 & 0,80 & 24,42 \\
\hline & 70 & 0,80 & 32,08 \\
\hline \multirow{3}{*}{1,10} & 50 & 1,10 & 44,41 \\
\hline & 60 & 1,10 & 23,20 \\
\hline & 70 & 1,10 & 50,66 \\
\hline
\end{tabular}

\section{Pengaruh Temperatur Pengeringan Terhadap Tensile Strength}

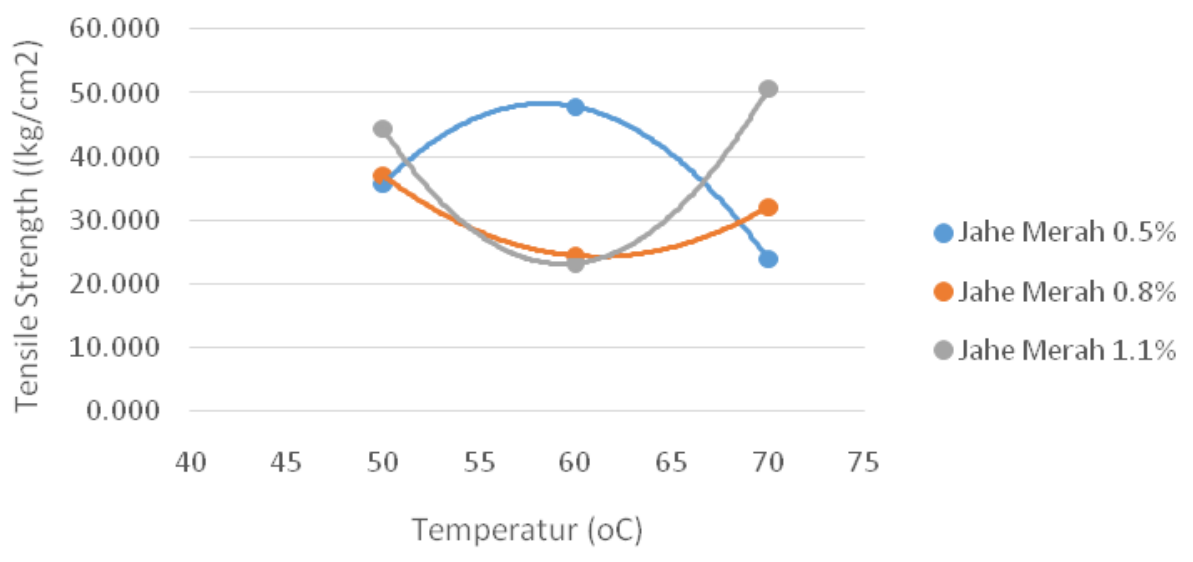

Gambar 3. Pengaruh Temperatur Pengeringan Terhadap Tensile Strength

Seperti terdapat pada gambar 3. Penambahan ekstrak jahe merah berpengaruh terhadap tensile strength pada edible film. Penambahan ekstrak jahe merah dapat mengurangi nilai tensile strength pada edible film karena mengakibatkan menghalangi terbentuknya ikatan silang antar rantai amilosa. Terputusnya ikatan antar rantai amilosa menyebabkan mudah terputusnya jaringjaring dalam edible film sehingga kuat tarik (tensile strength) film semakin menurun. Kecendrungan hasil yang serupa dengan
Kechichian et al, 2010 bahwa edible film dengan bahan baku pati dengan penambahan sejumlah bubuk antimikroba akan menyebabkan tensile strength menurun. Dari gambar 3 dapat terlihat bahwa nilai tensile strength tertinggi diperoleh pada penambahan ekstrak jahe merah $1.1 \%$ yaitu sebesar $50,66 \mathrm{~kg} / \mathrm{cm}^{2}$.

\section{KESIMPULAN (DAN SARAN)}

Nilai swelling dan tensile strength yang tertinggi diperoleh pada edible pati kulit singkong dengan penambahan ekstrak 
jahe merah $1.1 \%$ pada temperatur $70{ }^{\circ} \mathrm{C}$, dimana besarnya nilai swelling dan tensil strength masing-masing $88,89 \%$ dan $50,66 \mathrm{~kg} / \mathrm{cm}^{2}$.

\section{Daftar Pustaka}

bbp4b.litbang.kkp.go.id diakses pada 1 oktober 2016 pukul 22:01 WIB.

Cuzin, N.,Farinet, J.L.\& Segretain, C. 1991. Anaerobic fermentation of solid cassava wastes in continuous pilot scale fermenter. In: Grassi G, Delmon B, Molle JF, Zibetta H (eds) Biomass for Energy and Industry 4th E.C. Conference Elsevier Applied Science, London, pp. 2383-2387

Gennadios, A and C.L.Weller.(1990)."Moisture Adsorption by grain Protein

Hui, Y. H. 2006, Handbook of Food Science, Technology, and, Engineering Volume I. CRC Press, USA

Krochta, J,M,. 1994, "Edible coating And Films to Improve food Quality", CRC Press Boca raton, New York.

Prihatiningsih, N. 2000. Pengaruh penambahan sorbitol dan asam palmitat terhadap ketebalan film dan sifat mekanik edible film dari zein. Jurusan Teknologi Hasil Pertanian, Fakultas Teknologi Pertanian, Universitas Gadjah Mada, Yogyakarta.

Suryana, Achmad. 2005. Seminar Kebijakan Pertahanan Pangan. Bogor Faberta, IPB. 